\title{
分析建筑工程地基基础与桩基检测技术应用
}

邓珊珊

滨州市滨城区建设工程材料检测站 山东滨州 256600

DOI 号:10.18686/bd.v1i4.274

[摘 要] 当前社会中, 建筑的工程项目多种多样, 当然施工技术与工艺也各不相同, 作为当前建筑行业最基本的技术建 筑工程地基基础与桩基检测技术的应用, 将会为当前的建筑业带来不一样的便利, 但是, 这一环节也是必不可少的, 基础也 就意味着意义重大, 基础也就意味着要求更高。所以, 就本文而言, 我们根据当前建筑工程中的地基基础与桩基检测技术的 概念及重要性做了深度的阐述, 着重探讨了地基基础与桩基检测技术在建筑工程的应用及未来的发展趋势走向。

[关键词］地基基础;桩基础;检测技术

\section{1 地基基础与桩基础的概念}

在建筑工程中地基是指建筑物荷载作用下，基底下方 产生变形的那部分地层。而基础则是指将建筑物荷载有效 传递给地基的建筑下部结构。地基作为建筑物荷载的重要 支撑, 必须对强度破坏及失稳现象进行有效的预防。另外, 基础的沉降量也必须控制在地基变形的允许范围内。在建 筑工程中, 地基如果能够满足上述要求及条件, 就应该在施 工过程中尽量选择埋深较浅的, 施工程序尽量简单有效的 基础类型及技术措施,也就是天然地基上的浅基础形式; 而 当地基的条件不能满足上述条件及要求时, 则应该选择合 理的地基加固处理措施, 使地基的稳定性和强度得到一定 程度的提高。

\section{1 换土垫层}

通常情况下建筑工程地基施工时, 容易遇到湿润膨胀 性土体, 这种土体的承载力较小, 地基的稳定性和强度得不 到保障。因此, 可采用换垫层法来处理原地基土。换置土垫 层的方法是指采用砂石等强度较高的材料, 将原地基中的 浅层软土换除, 从而减小土层的湿陷性和胀缩性, 有效提高 地基的承载力, 使地基的沉降量减少。一般建筑工程中所采 用的垫层土主要有素土垫层、砂垫层以及碎石垫层等。这种 方法通常应用于处理浅层的软弱土、湿陷性黄土或者季节 性冻土的地基当中。施工需要采用分层填土的方式来, 来预 防施工时产生的土体孔洞及缝隙, 从而提高土体的密实 度。

\section{2 碾压及夯实}

在对地基强度有更高要求时, 可在施工过程中采用碾 压及夯实的方法, 使相对松软土层的密实度得到提升。碾压 及夯实法是指通过各种机械工具, 来对地基土产生强大的 夯击力作用, 在夯击力的作用下, 提高地基土的强度, 同时 改善土体的液化性能。碾压及夯实方法的运用, 能够最大限 度的减少建筑竣工后地基产生的沉降量。通常碾压及夯实 法包括机械碾压法和振动夯实法两种。

1.3 排水固结法

通常由于土壤的液化性质, 会使土层中含有一定的水
分, 使地基的承载力降低, 要想使土层固结就必须将水分排 除。排水固结就是指采用一系列有效的排水法, 将松散土体 中的水分排除并自动固结。在建筑工程中排水法对提高地 基承载力, 减少沉降量具有一定的效果。而且排水法处理技 术操作简、取材方便, 经济实用。具体方法是在地基周围设 置好袋装砂井、塑料排芯板, 然后采用水冲法或沉管法来成 孔, 并在孔内进行灌砂预压, 通过真空加压的方式来快速排 除地基土中的水分, 同时提高地基土的固结速度, 从而改善 土质的液化性质, 提高土层的强度, 减少沉降量。排水固结 法比较适合应用于淤泥土质、沼泽土、饱和性粘土等土层的 建筑地基工程中。

\section{2 桩基检测技术}

对桩基进行检测主要是注重对三方面的检测, 分别为 检测成孔质量、检测桩基承载力、检测桩基完整性。其中检 测桩基承载力时, 可以采用两种方法: 静荷载试验、高应变 动检测。而检测桩基完整性时, 可以采用低应变动、声波透 视两种方法。

\section{1 检测成孔质量}

进行桩基建设时, 成孔的质量关系到成桩的质量: 桩孔 的孔径过小时会降低整个桩基的的承载力; 桩孔上部扩径 时会增大成桩上部的侧阻力, 而下部侧阻力得不到完全发 挥; 桩孔偏斜时使桩基承载力不能够得到有效的发挥; 过厚 的桩底沉渣减少了有效桩长。因此, 检测成孔质量是保证成 桩质量最为重要的环节。检测成孔质量主要是检测桩孔位 置, 检测孔深、孔径, 检测垂直度以及检测沉渣厚度等。

\section{2 检测桩基承载力}

(1)静荷载试验法。作为检测桩基承载力的方法之一, 静 荷载试验主要是检测基桩坚向以及水平承载力, 其中坚向 静荷载被广泛应用于建筑工程中。静荷载试验以桩基实际 受力为试验参照标准, 尽可能贴近实际情况, 这也是其最为 突出的特点。静载试验应用于检测工程试桩, 具有较高的精 确度,一般将误差控制在 $10 \%$ 以内。

(2)高应变动检测。高应变动检测的主要原理是通过重 锤进行瞬态冲击桩顶, 然后使桩基周围的土塑性变形, 运用 
应力波理论对桩土体系进行分析并得到有关参数, 进而揭 示在接近极限时桩土体系的工作性能, 并对桩身质量做出 相关分析, 从而得到桩基极限状态的承载力。

2.3 检测桩基完整性

(1)低应变动检测。低应变动检测就是通过施加微量的 激振给桩顶, 使桩身以及其周围的土体产生微振, 并在这时 用仪表对桩顶振动的频率以及其加速度进行测量记录, 然 后运用波动理论认真分析记录结果, 从而完成对桩基施工 质量的检测、明确桩身的完整性, 并对基桩承载力做出适当 的预估等。

(2)声波透射法。声波透射法原理是通过分析混凝土中 超声波传播的相关声学参数的变化以及其波形, 进而判断 出桩身混凝土是否具有连续性, 同时对断层、蜂窝等缺陷做
出判断, 明确其大小与位置。

综上所述, 就目前的建筑行业的发展趋势来看, 我们发 现,伴随着人民对建筑住房的要求越来越高,基础的设施建 设才是必不可少的。因为基础的设施建设决定着整体的发 展方向, 对保证建筑工程的项目质量和项目管理水平起着 尤为重要的作用。所以,我们要根据建筑工程项目中的不同 要求, 求同存异, 采取不一样的施工方案和技术进而提高工 程质量和进度。

\section{参考文献}

[1].杨春梅, 关于现代房屋建筑地基基础工程施工的 论述[J].中国新技术新产品, 2012(7): 176 .

[2].王大超, 陈国辉, 工业厂房地基基础与桩基础土建 施工技术[J].民营科技, 2011,(7):281。 